\title{
Effect of toxic gases on human erythrocytes: Spectrophotometric analysis.
}

1. M.Phil

Lecturer Biochemistry

Frontier Medical and Dental College, Abbottabad.

2. Ph.D

Assistant Professor Biochemistry Shahida Islam Medical and Dental College, Lodhran

3. MBBS, M.Phil

Associate Professor Pathology Mohi-ud-Din Islamic Medical College, Mirpur, AJK

4. Ph.D

Associate Professor Chemistry Hazara University, Mansehra.

Correspondence Address:

Dr. Khawar Anwar Department of Biochemistry

Shahida Islam Medical and Dental

College, Lodhran.

khawarkk2@gmail.com

Article received on:

13/10/2020

Accepted for publication:

$12 / 02 / 2021$

\section{Errum Bashir ${ }^{1}$, Khawar Anwar ${ }^{2}$, Muhammad Usman Anjum ${ }^{3}$, Wajid Rehman ${ }^{4}$}

ABSTRACT... Objective: This study was carried out to analyze the influence of various toxic gases on human erythrocytes. Study Design: Experimental study. Setting: Department of Chemistry, Hazara University, Mansehra. Period: January 2017 to June 2017. Material \& Methods: Erythrocytes were isolated and prepared by the standard method from blood samples. The standard absorption spectra were recorded in the range of 200-800nm using double-beam UV-visible spectrophotometer. Gases were prepared in laboratory as per given protocol. Erythrocyte samples were treated with prepared gases. Absorbance of the samples was recorded. The spectrum of these treated samples was compared with the standard spectra of erythrocytes to check for any changes that might have occurred. Results: It was observed that erythrocytes exhibiteded altered behavior with each gas which was confirmed by shift in peaks in UV/Visible spectra. Absorption maxima were shifted from higher to lower wavelengths and this shift was more pronounced in case of Chlorine, Carbon Monoxide and Carbon Dioxide as compared to that observed in case of Hydrogen Sulfide, Sulfur dioxide, and Nitrogen Dioxide. Conclusion: This study showed that erythrocytes exhibit different behavior with different gases as evident by the shift of peaks in UV/Visible spectra. The absorption maxima were shifted towards lower wavelengths suggesting that these gases do exert an effect on human erythrocytes. The lipid site of erythrocytes, being sensitive for absorbing various atmospheric gases, caused deformation of original erythrocyte structure and altered their activity. This type of interaction of red blood cells with such external species, particularly the donor-acceptor case, caused damage to erythrocytes and in turn, decreased their number.

Key words: $\quad$ Erythrocytes, Gases, Spectrophotometer, Spectrum, Toxic.

Article Citation: Bashir E, Anwar K, Anjum MU, Rehman W. Effect of toxic gases on human erythrocytes: Spectrophotometric analysis. Professional Med J 2021; 28(10):1525-1530. https://doi.org/10.29309/TPMJ/2021.28.10.6354

\section{INTRODUCTION}

Air pollution is a serious problem which threatens human health globally for a long time. There are different contributing sources of air pollution which can be a small unit of cigarettes to a huge amount of toxic gases produced from fossil fuel combustion in motor engines of vehicles and industrial expansions. ${ }^{1,2}$ Serious diseases like respiratory infections, cardiovascular diseases and cancers are the major manifestations of continuous exposure to these toxic gases. Globally, Millions of deaths are associated with environmental pollutants each year. ${ }^{3-5}$ Sterility in male is also linked with air pollution in the latest research. ${ }^{6}$

Some of the main aerial pollutants include sulfur dioxide $\left(\mathrm{SO}_{2}\right)$, nitrogen dioxide $\left(\mathrm{NO}_{2}\right)$, carbon monoxide (CO) and ozone $\left(\mathrm{O}_{3}\right) . \mathrm{SO}_{2}$ is described to cause a rise in the daily number of deaths due to cardiovascular and respiratory illnesses. It absorbs readily (99\%) through the respiratory tract and displays a wide spread tissue-distribution. ${ }^{7,8}$ Amount of $\mathrm{SO}_{2}$ in blood and other tissues increases proportionately with the concentration of $\mathrm{SO}_{2}$ in inhaled air. Radioactive sulfur (S35) could be identified in the protein segments of tissues for at least one week. ${ }^{9}$ Chow and Hong reported an increase in lipid peroxidation, in rats, of the heart and lung tissues as a result of $\mathrm{SO}_{2}$ inhalation at the rate of $10 \mathrm{ppm}$ for one hour daily for thirty days. ${ }^{4}$ Substantial rise in sulfhemoglobin ratios and erythrocyte activities of superoxide dismutase and glutathione peroxidase, due to exposure to 
heavy air pollution, were also reported. ${ }^{4,10}$ Various studies reported $\mathrm{SO}_{2}$ inhalation induced increase in sulfhemoglobin and osmotic fragility ratios, leucocyte and erythrocyte count, hematocrit and hemoglobin levels. ${ }^{11}$ Hence, inhalation of several air pollutants $\left(\mathrm{NO}_{2}, \mathrm{O}_{3}\right.$, cigarette smoke) was described to lead to an increase in osmotic fragility ratios and MDA levels. ${ }^{12,13}$ Long term exposure to these toxic gases in humans, even at low concentrations, is very hazardous. Therefore, this study was conducted to analyze the effects of various toxic gases on erythrocytes.

\section{MATERIAL \& METHODS}

This study was performed at Department of Chemistry, Hazara University, Mansehra, from January 2017 to June 2017. Blood samples were collected from clinical laboratory under aseptic conditions and erythrocytes were separated and prepared by the method of Dodge et al. The standard absorption spectrums were measured, (range: 200-800nm), using double-beam UVvisible spectrophotometer (PerkinElmer, USA).

Gases were prepared in laboratory as follows:

\section{Carbon dioxide gas}

$\mathrm{CO}_{2}$ was prepared by reacting calcium carbonate $\left(\mathrm{CaCO}_{3}\right)$ with Hydrochloric acid $(\mathrm{HCl})$ as follows: $\mathrm{CaCO}_{3}+\mathrm{HCl} \rightarrow \mathrm{CaCl}_{2}+\mathrm{H}_{2} \mathrm{O}+\mathrm{CO}_{2}$

\section{Carbon monoxide gas}

CO gas was prepared by reacting Zinc (Zn) metal with Calcium Carbonate $\left(\mathrm{CaCO}_{3}\right)$ as follows:

$\mathrm{Zn}+\mathrm{CaCO}_{3} \rightarrow \mathrm{ZnO}+\mathrm{CaO}+\mathrm{CO}$

\section{Sulphur dioxide gas}

$\mathrm{SO}_{2}$ gas was prepared by reacting Copper (Cu) metal with Sulphuric acid $\left(\mathrm{H}_{2} \mathrm{SO}_{4}\right)$ with following chemical reaction; $\mathrm{Cu}+2 \mathrm{H}_{2} \mathrm{SO}_{4} \rightarrow \mathrm{CuSO}_{4}$ $+\mathrm{SO}_{2}+2 \mathrm{H}_{2} \mathrm{O}$

\section{Chlorine gas}

$\mathrm{Cl}_{2}$ gas was prepared by reacting manganese dioxide $\left(\mathrm{MnO}_{2}\right)$ with hydrochloric acid $(\mathrm{HCl})$ as follows: $\mathrm{MnO}_{2}+4 \mathrm{HCl} \rightarrow \mathrm{MnCl}_{2}+2 \mathrm{H}_{2} \mathrm{O}+\mathrm{Cl}_{2}$

\section{Hydrogen sulphide gas}

$\mathrm{H}_{2} \mathrm{~S}$ was prepared by reacting iron pyrite (FeS) with Sulphuric acid $\left(\mathrm{H}_{2} \mathrm{SO}_{4}\right)$ as follows:

$\mathrm{FeS}+\mathrm{H}_{2} \mathrm{SO}_{4} \rightarrow \mathrm{FeSO}_{4}+\mathrm{H}_{2} \mathrm{~S}$

\section{Nitrogen dioxide gas}

$\mathrm{NO}_{2}$ was prepared by reacting nitric acid $\left(\mathrm{HNO}_{3}\right)$ with tin (Sn) and $\mathrm{NO}_{2}$ gas was produced a byproduct. $4 \mathrm{HNO}_{3}+\mathrm{Sn} \rightarrow \mathrm{H}_{2} \mathrm{O}+\mathrm{H}_{2} \mathrm{SnO}_{3}+$ $4 \mathrm{NO}_{2}$

Erythrocyte samples were then treated with these prepared gases. Absorbance of the gas treated samples was recorded on double beam UVVisible Spectrophotometer in the range of 200$800 \mathrm{~nm}$. Recorded spectra of these samples were compared with standard erythrocyte spectra to analyze for any changes that might have occurred.

\section{RESULTS}

This study examined the impact of different toxic gases such as $\mathrm{CO}_{2}, \mathrm{CO}, \mathrm{SO}_{2}, \mathrm{Cl}_{2}, \mathrm{H}_{2} \mathrm{~S}$, and $\mathrm{NO}_{2}$, which were normally released during industrial processes from different sources, on the human erythrocytes. Our study showed that the standard normal erythrocyte spectrum showed maximum absorption at 537nm as shown in Figure-1.

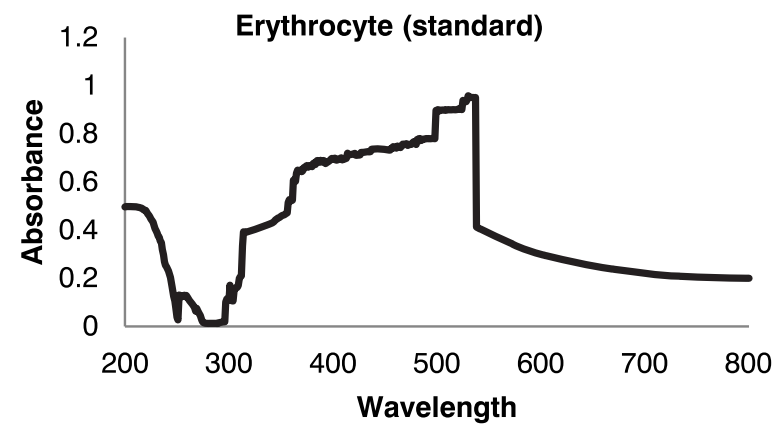

Figure-1. Standard normal erythrocyte absorption spectrophotometric spectra.

Erythrocytes were treated with toxic gases which were prepared in the laboratory. After treating the erythrocyte samples with these toxic gases, there was a change in the observed spectra. Carbon dioxide and carbon monoxide displayed similar effect on treated erythrocytes as the absorption maxima was obtained at 533nm (for $\mathrm{CO}_{2}$ ) and $532 \mathrm{~nm}$ (for $\mathrm{CO}$ ). The spectrum exhibited a minor shift downwards as shown in Figure-2 and 3 respectively. 


\section{Effect of Carbon Monoxide}

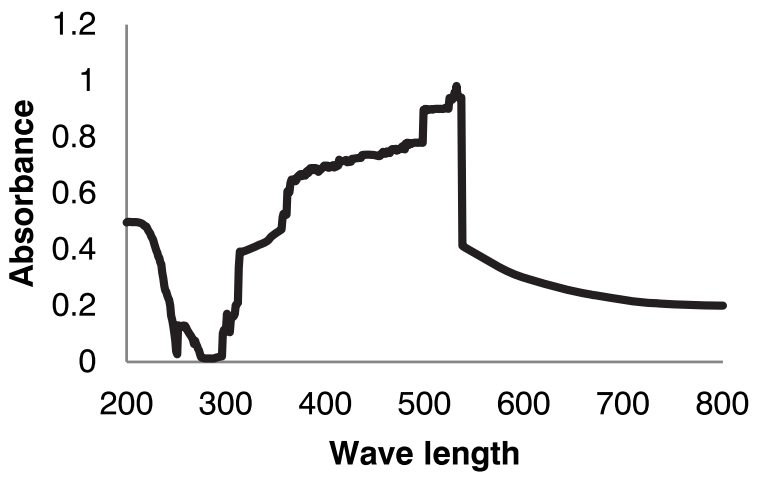

Figure-2. Spectrophotometric absorption spectrum for CO treated erythrocytes.

\section{Effect of Carbon Dioxide}

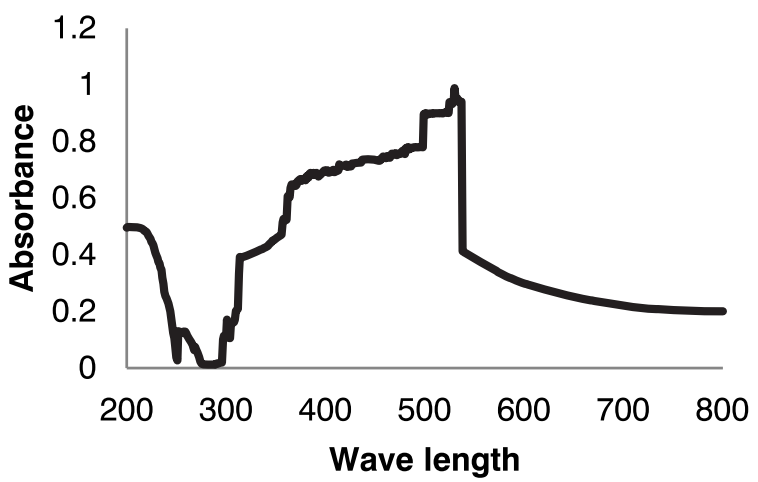

Figure-3. Spectrophotometric absorption spectrum for $\mathrm{CO}_{2}$ treated erythrocytes.

Sulfur dioxide treated erythrocytes displayed absorption spectra at $526 \mathrm{~nm}$ and $512 \mathrm{~nm}$, as displayed in Figure-4. There were new peaks in $\mathrm{SO}_{2}$ exposed erythrocyte spectra showing that some new compounds were formed with changing intensities.

Chlorine, hydrogen sulfide, and nitrogen dioxide gas treated samples of erythrocytes showed absorption maxima at 498nm, 526 and 495 as shown in Figures-5, 6 and 7 respectively. These changes could be attributed to interaction of these gases with iron which was present in hemoglobin. Specifically after treatment with $\mathrm{NO}_{2}$, it appeared that vital bands of erythrocyte had disappeared and some new compounds were formed by the process of interactions and complications.
Effect of Sulphur Dioxide

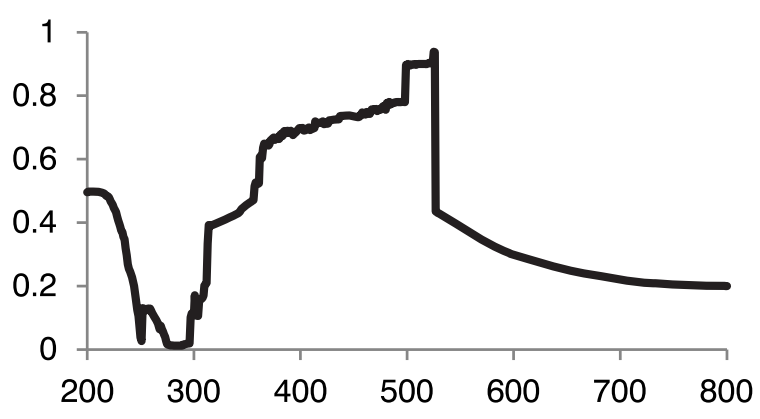

Figure-4. Spectrophotometric absorption spectrum for $\mathrm{SO}_{2}$ treated erythrocytes.

\section{Effect of Hydrogen Sulphide}

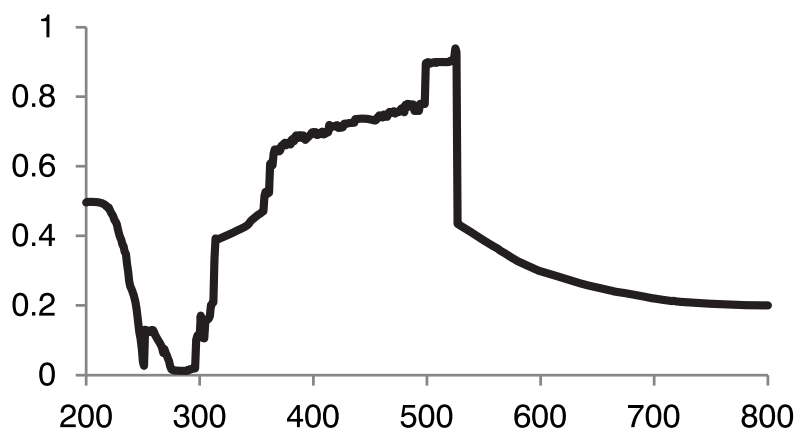

Figure-5. Spectrophotometric absorption spectrum for $\mathrm{Cl}_{2}$ treated erythrocytes.

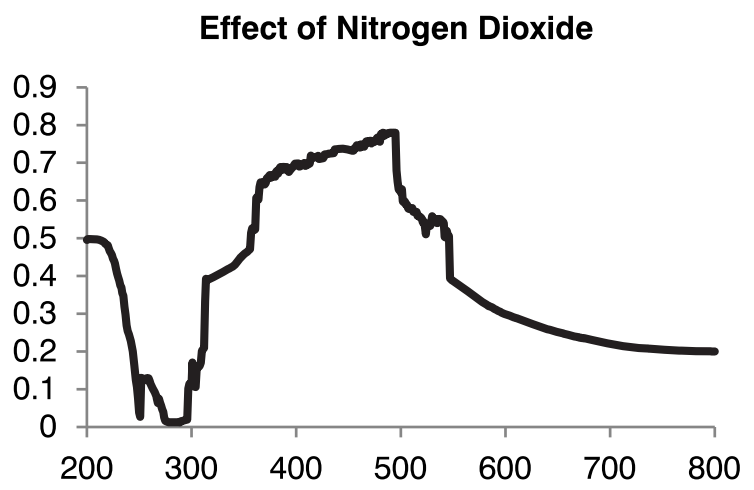

Figure-6. Spectrophotometric absorption spectrum for $\mathrm{H}_{2} \mathrm{~S}$ treated erythrocytes. 


\section{Effect of Chlorine}

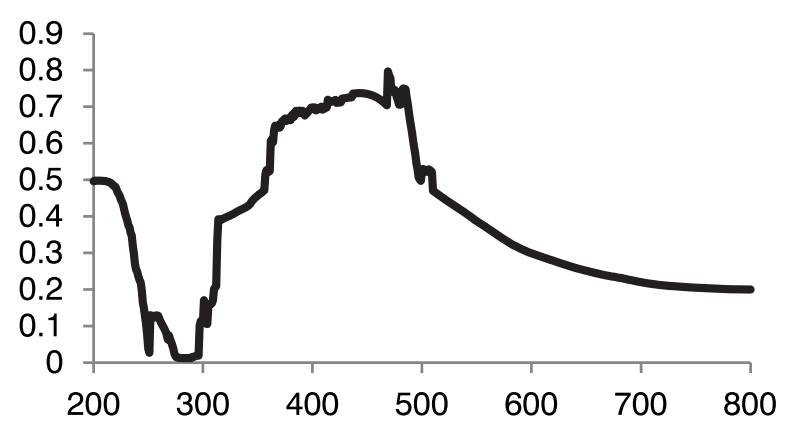

Figure-7. Spectrophotometric absorption spectrum for $\mathrm{NO}_{2}$ treated erythrocytes.

\section{DISCUSSION}

Interaction of erythrocytes with various gases like Carbon monoxide, Carbon dioxide, Chlorine, Hydrogen Sulphide, Sulphur dioxide, and Nitrogen Dioxide was analyzed.

\section{Carbon Monoxide and Carbon Dioxide}

$\mathrm{CO}$ and $\mathrm{CO}_{2}$ showed absorption maxima at 530 and $532 \mathrm{~nm}$ respectively. Interactions of $\mathrm{CO}$ and $\mathrm{CO}_{2}$ with the carboxylic group of hemoglobin resulted in greenish-red appearance.

These gases enter the body via inhalation, contact through skin and eye. Symptoms include headaches, seizures, dizziness, and hallucination. ${ }^{14}$ Typically, both these gases behave in a similar pattern. Though, the extensive concentration of $\mathrm{CO}$ lead to paucity of blood oxygen because of high affinity of hemoglobin for CO. ${ }^{15}$

\section{Sulfur Dioxide}

It is a byproduct of burning of coal and other fossil fuels. Moreover, other natural sources of atmospheric $\mathrm{SO}_{2}$ include volcanoes, marine and terrestrial biogenic discharges. ${ }^{9}$

Resulting UV/Visible spectra after $\mathrm{SO}_{2}$ treatment of erythrocytes showed that there was interaction of $\mathrm{SO}_{2}$ with erythrocytes which lead to changes in bands in spectra. Interaction of lone pair of electrons on sulfur and oxygen of red blood cells resulted in alteration in band from $350 \mathrm{~nm}$ to $450 \mathrm{~nm}$. Appearance of two other bands at $510 \mathrm{~nm}$ and $536 \mathrm{~nm}$ indicated that there was some kind of bonding among $\mathrm{SO}_{2}$ and erythrocyte active locations which caused the quantity of red blood cells to reduce considerably. ${ }^{16,17}$

\section{Chlorine}

Mostly, exposure to chlorine occurs via inhalation and low-level exposure to chlorine in air will lead to skin, eye or airway irritation, cough and sore throat while exposures at higher levels result in the dyspnea, wheezing, chest tightness and bronchospasm. Severe exposures to chlorine could lead to non-cardiogenic pulmonary edema and it could be delayed for many hours. ${ }^{18}$

Absorption maxima in case of chlorine treated erythrocytes shifted from $537 \mathrm{~nm}$ to $470 \mathrm{~nm}$. This shift could be attributed to the interaction of chlorine with the hydrogen of erythrocytes. It has been proposed that lowering of absorption maxima due to chlorine was because of absorption of chlorine in the lipid layer of erythrocytes which eventually lower the number of erythrocytes. ${ }^{19}$ It was also reported that the long-time chlorine exposure of erythrocytes may lead to severe clotting abnormality which in the end causes death. ${ }^{20}$

\section{Hydrogen Sulfide}

Hydrogen sulfide leads to inhibition of the cytochrome oxidase enzyme system which causes dearth of oxygen for use in cells and tissues. As a result, an acid-base imbalance ensues because of anaerobic metabolism which causes buildup of lactic acid. Cardiac and nervous tissues are chiefly susceptible to the disturbance of oxidative metabolism and death may occur due to respiratory arrest.

$\mathrm{H}_{2} \mathrm{~S}$ gas treated samples of erythrocytes showed absorption maxima at $526 \mathrm{~nm}$. The UV/Visible spectra after treating erythrocytes with $\mathrm{H}_{2} \mathrm{~S}$ was comparable to that of spectra of $\mathrm{SO}_{2}$ treated sample. This confirmed that the sulfur played a key part in shifting the absorption spectra in both cases. This shifting of absorption spectra could be attributed to the interaction of sole pair of 
electrons on sulfur and oxygen of red blood cells

\section{Nitrogen Dioxide}

Nitrogen Oxides $\left(\mathrm{NO}_{2}\right)$ are a group of gases which cause numerous severe health issues. They react with ammonia and other compounds to form nitric acid and other interrelated compounds. These minute particles damage lung tissue and effects breathing and can even cause premature death. These trivial particles could infiltrate deeply into sensitive areas of respiratory system and might lead to or exacerbate lung diseases, for example emphysema and bronchitis, as well as worsen pre-existing heart disease..$^{21,22}$

$\mathrm{NO}_{2}$ treated erythrocytes showed the shifting of absorption maxima. Presence of electrons in nitrogen and oxygen, which were available for bonding with the active sites of red blood cells, might be responsible for this shift. Longtime exposure of erythrocytes to $\mathrm{NO}_{2}$ also effects the $\mathrm{pH}$ of red blood cells as both active groups ( $\mathrm{N}$ and $\mathrm{O}$ ) serve as a bridge among erythrocytes and $\mathrm{NO}_{2}$. As a result, the number of erythrocytes decreased $^{23}$ which may in turn cause serious diseases.

This study revealed that erythrocytes displayed altered behavior with each gas analyzed. There was a shift in absorption maxima from higher to lower wavelength with each gas used and this shift was more pronounced in cases of Chlorine, Carbon Monoxide and Carbon Dioxide.

\section{CONCLUSION}

This study showed that erythrocytes exhibit different behavior with different gases as evident by the shift of peaks in UV spectra. Absorption spectra shifted from higher to lower wavelengths and this shift was more considerable and noticeable in case of Chlorine and Carbon Dioxide, Hydrogen Sulphide and Nitrogen Dioxide suggesting that these gases do have an effect on human erythrocytes. The lipid site of erythrocytes, being sensitive for absorbing various atmospheric gases, caused deformation of original erythrocyte structure and altered their activity. This type of interaction of red blood cells with such external species, particularly the donor- acceptor case, caused damage to erythrocytes and in turn, decreased their number.

\section{Copyright $\odot 12$ Feb, 2021.}

\section{REFERENCES}

1. Robinson DL. Air pollution in Australia: Review of costs, sources and potential solutions. Health promotion journal of Australia: official journal of Australian Association of Health Promotion Professionals. 2005; 16(3):213-20.

2. Habre R, Coull B, Moshier E, Godbold J, Grunin A, Nath $A$, et al. Sources of indoor air pollution in New York City residences of asthmatic children. Journal of exposure science \& environmental epidemiology. 2014; 24(3):269-78.

3. Biggeri A, Bellini P, Terracini B. Meta-analysis of the Italian studies on short-term effects of air pollutionMISA 1996-2002. Epidemiologia e prevenzione. 2004; 28(4-5 Suppl):4-100.

4. Chow CK, Hong CB. Dietary vitamin E and selenium and toxicity of nitrite and nitrate. Toxicology. 2002; 180(2):195-207.

5. Vermaelen K, Brusselle G. Exposing a deadly alliance: Novel insights into the biological links between COPD and lung cancer. Pulmonary pharmacology \& therapeutics. 2013; 26(5):544-54.

6. Zhou N, Cui Z, Yang S, Han X, Chen G, Zhou Z, et al. Air pollution and decreased semen quality: $A$ comparative study of Chongqing urban and rural areas. Environmental pollution (Barking, Essex: 1987). 2014; 187:145-52.

7. Jarnefelt J, Rush J, LiYT, Laine RA. Erythroglycan, a high molecular weight glycopeptide with the repeating structure [galactosyl-(1 leads to 4)-2-deoxy-2acetamido-glucosyl (1 leads to 3 )] comprising more than one-third of the protein-bound carbohydrate of human erythrocyte stroma. J Biol Chem. 1978; 253(22):8006-9.

8. Yamashita N, Tanemura H, Kawanishi S. Mechanism of oxidative DNA damage induced by quercetin in the presence of $\mathrm{Cu}(\mathrm{II})$. Mutat Res. 1999; 425(1):107-15.

9. CARB CARB. California administrative code, regarding the short-term (one-hour) state ambient air quality standard for sulfur dioxide and measurement method. Public hearing to consider amendments to Section 70100(I) and 70200, Title 17, Staff report Sacramento (CA): 1983. 
10. Bony V, Gane P, Bailly P, Cartron JP. Time-course expression of polypeptides carrying blood group antigens during human erythroid differentiation. British journal of haematology. 1999; 107(2):263-74.

11. Akerman ME, Chan WC, Laakkonen P, Bhatia SN, Ruoslahti E. Nanocrystal targeting in vivo. Proc Natl Acad Sci U S A. 2002; 99(20):12617-21.

12. Valic B, Pavlin M, Miklavcic D. The effect of resting trans membrane voltage on cell electro permeabilization: A numerical analysis. Bio electrochemistry. 2004; $63(1-2): 311-5$.

13. Bogdanova AY, Gassmann M, Nikinmaa M. Copper ion redox state is critical for its effects on ion transport pathways and methaemoglobin formation in trout erythrocytes. Chemico-biological interactions. 2002; $139(1): 43-59$.

14. Rice SA. Human health risk assessment of CO2: Survivors of acute high level exposure and populations sensitive to prolonged low level exposure. Third annual conference on carbon sequestration May 3-6, 2004, Alexandria, Virginia USA. 2004.

15. Sharma RP, McQueen EG. Effects of gold sodium thiomalate on cytosolic copper and zinc in the rat kidney and liver tissues. Clin Exp Pharmacol Physiol. $1981 ; 8(6): 591-9$.
16. Zhang B, Liu CY, Meng ZQ. Study of toxicity on male reproductive system of mice induced by $\mathrm{SO} 2$ inhalation. Wei Sheng Yan Jiu. 2005; 34(2):167-9.

17. Etlik O, Tomur A, Kutman MN, Yorukan S, Duman O. The effects of sulfur dioxide inhalation and antioxidant vitamins on red blood cell lipoperoxidation. Environ Res. 1995; 71(1):25-8.

18. Mrugesh T DL, Manishika G. Toxic effect of Industrial Gases, Department of Earth and Environmental Sciences, KSKV Kachchh University, Mundra Road, Bhuj-370 001, Kachchh, India. 2009.

19. Halliwell B, Aruoma OI. DNA damage by oxygenderived species. Its mechanism and measurement in mammalian systems. FEBS Lett. 1991; 281(1-2):9-19.

20. Hsiao KJ. Genetic disorders and neonatal screening. Progress in Clinical Biochemistry New York, Elsevier Science Publisher, 289-292. 1992.

21. Jensen FB. Nitrite disrupts multiple physiological functions in aquatic animals. Comp Biochem Physiol A Mol Integr Physiol. 2003; 135(1):9-24.

22. Roehm JN, Hadley JG, Menzel DB. Oxidation of unsaturated fatty acids by ozone and nitrogen dioxide. A common mechanism of action. Arch Environ Health. 1971; 23(2):142-8.

23. Baskurt O LE, Caglayan S, Dikmenoglu N, Kutman MN. Hematological and hemorheological effects of air pollution. Arch Environ Health. 1990; 45:224-8.

\begin{tabular}{|c|l|l|l|}
\hline \multicolumn{3}{|c|}{ AUTHORSHIP } & AND CONTRIBUTION DECLARATION \\
\hline Sr. \# & Author(s) Full Name & \multicolumn{1}{|c|}{ Contribution to the paper } & Author(s) Signature \\
\hline 1 & Errum Bashir & $\begin{array}{l}\text { Conceived the idea, Study design } \\
\text { and performed study. } \\
\text { Proof-read, Critical revision and } \\
\text { final approval of the manusctipt. } \\
\text { Gathered and organized data, } \\
\text { Written manuscript. }\end{array}$ \\
\hline 3 & Khawar Anwar & M. Usman Anjum & Supervised the study. \\
\hline 4 & Wajid Rehman & Suld \\
\hline
\end{tabular}

